\begin{tabular}{|c|c|}
\hline & Volume \& Issues Obtainable at The Women University Multan \\
\hline
\end{tabular}

\title{
Safety and Security Issues of Media Professional: A Case Study of Freelance Journalists in Pakistan
}

\section{Syed Wasim Raza ${ }^{1}$, Azadi Fateh², Muhammad Aamir Shahzad ${ }^{3}$ Ayaz Khan $^{4}$}

${ }^{1}$ Ph.D. Scholar, Department of Mass Communication, Federal Urdu University of Arts, Science and Technology, Karachi.

${ }^{2}$ Assistant Professor, Department of Mass Communication, Federal Urdu University of Arts, Science and Technology, Karachi.

${ }^{3}$ M.Phil, Department of Sociology, University of Sargodha,Sargdha.

${ }^{4}$ Ph.D. Scholar, Department of Mass Communication, Federal Urdu University of Arts, Science and Technology, Karachi.

\begin{tabular}{|c|c|c|}
\hline \multicolumn{2}{|c|}{ ARTICLE DETAILS } & \multirow{3}{*}{$\begin{array}{l}\text { ABSTRACT } \\
\text { In the last twenty years' Pakistani media have } \\
\text { experienced remarkable progress and } \\
\text { transformation in its role. There have been serious } \\
\text { setbacks in current years. Almost more than one } \\
\text { hundred private TV channels are currently } \\
\text {-broadcasting. Pakistan is one of the unsafe counties } \\
\text { of the world for journalists as per the } 2020 \text { report }\end{array}$} \\
\hline $\begin{array}{l}\text { History: } \\
\text { Received: } \\
\text { Review: } \\
\text { Accepted: } \\
\text { Available Online: }\end{array}$ & $\begin{array}{l}\text { November 03,2021 } \\
\text { November 20, } 2021 \\
\text { December 26, } 2021 \\
\text { December 31, } 2021\end{array}$ & \\
\hline \multicolumn{2}{|l|}{ Keywords: } & \\
\hline \multicolumn{2}{|c|}{ Pakistani Journalists } & of the International Federation of Journalists \\
\hline \multicolumn{2}{|l|}{ Safety Issues } & Pakistan. Pakistan has been a war zone for almost \\
\hline \multicolumn{2}{|l|}{ Case Study } & forty years, where 140 journalists were killed in \\
\hline \multirow{2}{*}{\multicolumn{2}{|c|}{$\begin{array}{l}\text { Freelancers } \\
\text { Qualitative Study }\end{array}$}} & Pakistan from 2000 to 2020 but still, Pakistani law \\
\hline & & does not guarantee journalists' safety. Are they \\
\hline \multicolumn{2}{|l|}{ DOI: } & $\begin{array}{l}\text { feeling safe and secure and which steps will be } \\
\text { important for journalists' security and safety? This }\end{array}$ \\
\hline \multicolumn{2}{|c|}{ 10.52700/assap.v2i2.103 } & $\begin{array}{l}\text { researcher is qualitative. The data have been } \\
\text { collected by conducting interviews and applying the } \\
\text { social responsibility theory to investigate, what is } \\
\text { about the freedom of speech because this theory } \\
\text { describes the claims that the journalist always plays } \\
\text { a responsible role of passing the information with } \\
\text { freedom and the task of the press is to make } \\
\text { journalism better. } \\
\text { ( } 2021 \text { The Authors, Published by WUM. This is an Open Access } \\
\text { Article under the Creative Common Attribution Non Commercial } \\
4.0\end{array}$ \\
\hline
\end{tabular}

Corresponding author's email address: wasimnaqvi99@gmail.com

\section{Introduction}

Now, media is the fourth pillar of the state, a foremost British member of parliament Lord 
Syed Wasim Raza, Dr. Azadi Fateh, Ayaz Khan

Macaulay had given this status of the media. In any republican government system, there 
must be three administrative bodies, 1- parliament, 2 - Administrative department, 3 Judiciary body but now it is fingered that one figure additional is essential to be with them that is media. Media plays a vigorous part in determining a strong and resilient democracy we can say that media is a pillar of social equality but unfortunately the workers of this fourth pillar facing dangerous situations all over the world. Since 1990 as a minimum of two thousand, two hundred and nighty seven journalists and media workers have been murdered and Pakistan is fourth on the list of the dangerous countries in the world for journalists after Mexico, the Philippines, and Iraq according to an International Federation of journalists (IFJ).

71 journalists and media workers have lost their breathe since 2001 to 2015 while following their responsibilities in Pakistan. Of these, 47 have been deliberately targeted and murdered for practicing their profession, while others were murdered during cover unsafe events. In only two cases have the murdered been convicted by the court one is Daniel pearl and the rest is Wali Khan Babar. Pakistani journalists are not only targeted by militants but also political parties, religious, ethnic, and other groups. Attackers and murderers of journalists enjoy impunity, which undermines the freedom of expression in the country. Pressures and violence have compulsory many correspondents to transfer from these threat zones and to leave the profession or to resort to self-censorship, particularly in conflict areas.

This research will be valuable to know about the safety and security issues of journalists in Pakistan and how many journalists feel secure and safe in Pakistan. It can also help to know that what steps should be taken from state /media owners for journalists. Why journalists feel insecure and how Pakistan can get a good name in the field of journalist securities. At least 140 journalists were killed in Pakistan from 1992-202, in those, 65 journalists were killed motive unconfirmed and rest are confirmed motived. As per the data of CJP the most dangerous years for a journalist are 2010 in those 10 journalists were killed and 2011 in those 11 journalists were killed. As per the report of "Freedom Network "Zero Justice for Pakistan's Journalists and media workers"

Sadly, most murderers in these cases remain faceless and unidentified. This, even though potential fears or alleged offenders are often doubted and well-known by the wounded and their relatives. The statement initiates that one in every three murder cases of journalists upsettingly contains state performers, political parties, and/or religious crowds. In 60 percent of the cases, the police were unsuccessful in comprehensive investigations into the unlawful death, therefore deteriorating to generate a final challan or a full examination report to submit before a court for trial.

\section{Literature Review}

World Press Freedom Index, Pakistan is ranked at number 142 out of 180 countries, measured in terms of providing a safe work atmosphere to journalists. You may ask why, in a place where many social groups are impacted by killing, reporters should matter in a larger background? Researchers have discussed that the right to freedom of expression is of specific suggestion to journalists because security and safety are fundamentals to journalists' specialized duties - particularly in Pakistan. Occurrences on journalists are attacks on the freedom of expression - and also on civil society and the very national itself. Today, it is not only media but common people down their freedom of expression to the decreased space for patience in our society. This condition calls for more responsible conduct from the broadcasting.

Along with the community insecurity, Pakistan poses physical restraints to journalists as well. In our North West area, the KPK (Federally Administered Tribal Area former FATA) is a nogo area for the mainstream media due to security threats. Similarly, there is no sovereign 

media presence in many regions of Baluchistan and Khyber Pakhtunkhwa. Journalists and newspapers often face death threats and density from the State as well as non-state actors in both subtle and overt ways. This frequently consequences in censorship and again, proves a major setback to the practice of freedom of expression. If the atmosphere is so dangerous, journalists come to trust that it is purely too unsafe to cover certain themes and options to self-censorship. In addition to fears and pressure from different stakeholders, there are no exact laws to protect journalists in Pakistan. Media rights fall into the same class as citizens' rights, and no device, therefore, exists to funnel any superior or vital cases of journalist security. This means cases go unexplained and the cases of misplaced journalists are not put on different motions in the law court where a usual case can delay on for ages. It's a cliché but it's true; justice delayed is justice denied. And when the voice of the people is stifled because of an unsuccessful justice structure, it covers the way for cumulative self-censorship of journalists.

Morals, trustworthiness, and security are interlinked in Pakistan. The country also absences correctly skilled journalists and there is a terrible essential for the official exercise of print, electronic and digital media journalists. A journalist's duty is to the fact at the end of the time. But other moral tests tell how the media is subsidized. To carry out their services, media houses trust announcements to produce funds. Troublingly, in Pakistan, there is a commercial 'mafia' that is considered to control many media corporations. The genuineness of journalistic responsibilities is under threat when journalists become responsible for promotion customers and other investors. Often, media houses have to opt between dropping short on funds or following the agenda of their promoters. This creates a key dent in the reliability and sustainability of reporting.

In adding to these subjects, sovereign journalism in Pakistan has not been common with the state. There is a general boldness of banning and editing of stories. Pakistan has been through various incidents of dangerous censorship since the beginning almost. For example, over the '1971 Press and Publication Ordinance' the rulers of the time straight skillful the role of media to serve their interests. In 2002 dictator general President Musharaf introduced "defamation Law" under legal framework ordinance (LFO) but KUJ and PFUJ showed their concerns about it and said it is against the freedom of the press. On $21^{\text {st }}$ August 2002 in Karachi, MD of KESC hit and injured the reporter of "Daily Nation" reporter "Aziz Sangho" who published reports against the bad performance of KESC.

In 2007, when the whole country was in political crisis, dictator Musharraf dismissed CJP Iftikhar Muhammad $\mathrm{Ch}$ from his seat. Lawyers started the movement against Musharraf action and the media played a vital role to cover all these activities then Dictator Musharraf want to control the electronic media and Passed Pemra Amendment Ordinance 2007, as per this Ordinance the state has full authority to ban and control the transmission of any channel even the state can abstain all the equipment of any channel.

On $3^{\text {rd }}$ November Dictator Musharraf impose an emergency and banned Geo TV, Dawn News, ARY News, and other channels and the other side those channels that could on air their transmission but the government banned their shows. The government also banned their advertisements to the government against channels and newspapers. Dr. Taussef Ahmed wrote in "Pakistan may Marsha Law kiTareekh" book which is organized by Dr. Mubarak Ali. In this book, Dr.Tauseef Ahmed described very vastly all those activities which were against the journalists or freedom of the Press from the first Marsha law of Dictator General Ayab Khan to Dictator General Musharaf Marsh law. How Dictators used their power on Media and what tactics they used to control Media in their favor. 
In "Media Barsar-e-Paikaar" book, Written by Syed Mujahid Ali, this was published after the attack of journalist Hamid Mir in Karachi on $19^{\text {th }}$ April 2014 and after this attack when Geo News nominated ISI Chief in this attack after that all government files case against geo in PEMRA but PEMRA divided into two groups, the two private members Main Shams ul Rehman and IsrarAbbasi of PEMRA who didn't have any journalistic background were in the favor to suspended Geo News, Geo Tez and Geo Entertainment licenses before all these circumstances cable operators already limited the transmission of Geo Network. This is the right of Editors that they can on-air any news rather then we can debate on it whether this news was right or wrong but just in this case nobody has to right to suspend the license of any channel similarly on $14^{\text {th }}$ May 2014, in Geo News Morning show "UthoJago Pakistan" when the case has been filed against program host ShaistaWahidi, Actress Veena Malik and her husband Asad Khattak in terrorist's courts in all over the country. The rightist side of people threaded responsible person and employees of Geo Network even the chief of Sunni Ittihad council Hamid Raza gave Fatwah against Geo Network that to Watch Geo is Haram (prohibited). In this society when nobody is safe if he/she is accused of Blasphemy.

ZameerNiazi wrote in his book "SahafatPabandiSalasal" that how states and Governments imposed their laws on Media and journalist, he also wrote that 'mistakes are also a part of freedom of Press or media" General Ayub khan made laws for journalist that how he controlled media, Dictator Ayub Khan issued Press and Publication ordinance in 1963, there are many laws were exist in Pakistan like 124(A) of Constitution of Pakistan recommended the punishment of journalists who wrote and speak against Pakistan, Article 153(A) can define the punishment of those journalists who write and speak radical and hate material to divide or violate among people, Article 499 and 500 the law of defamation can give the right to people that can sue against journalist similarly Article 295(A) punish those persons who wrote hated material against any sect or religion, As per Article 296 can punishment against vulgar material and Article 505 can punishment those journalist or people who motive uprising security forces against government or country.

Mr.ZameerNiazi defines very excellently that how governments and dictators use their powers against a journalist and he wrote all those things and events that were against the media or press. Every government and dictator made laws to control freedom of the press to control the journalist but nobody could work on the safety and security of journalists. Every government whether it is Marsha law government or Democratic government every one made laws and passed an ordinance that how media can use in the favor of our interest.

In a recent example of DAWN NEWSPAPER journalist Cyril Almaida who is a Weekly Columnist, wrote a story and leaked secrets of government and Forces meetings. The government made a commission on it that how secrets leaked. The government put Cyril's name in ECL and dismissed his information minister Parveez Rasheed to disclose secrets to Cyril but in this government tenure many journalists lost their lives and many were injured but the government did not take any action against the killers of them even the government did not take any commission on it because the government there is no interest in the favor of the government.

Mr. JavidJabbar wrote the book "Pakistan AnokhiTashkeelAnokhiTadeer". In this book, he wrote that till 2011 Pakistan has 113 satellite TV channels, 4 PTV channels, 116 FM Radio stations, and more than a thousand daily newspapers. Pakistani viewers can watch 26 international TV channels via 2335 license holder cable operators. Pakistani channels can air anything without pressure. Pakistani journalists gave their lives for media freedom. 
Yes, Mr.Jabbar said everything right but this is one side of the picture if we observe that nobody even he is a dictator or democratic person give freedom to media they always want to control over it. This is media's success or journalist's success that they snatch their freedom to the authorities or governments but still many things need to do for journalist's protection and their securities. Mr. Jabbar also worked as a senator in the senate of Pakistan but he did not write about the law regarding journalist's protection, he should write about it that when Pakistan is a dangerous country for journalists then why Pakistani parliament or senate did not make any law for the protection of journalist.

\section{Methodology}

This research will be qualitative as well as quantitative. The data will be collected by conducting interviews which will be used for data presentation as well as content analysis.

Social responsibility theory will be applied to this study for only one perspective which is about the freedom of speech. This theory describes the claims that a Journalist always plays a responsible role in passing the information with freedom and the tasks of the press are to make a code of conduct and follow it, to develop a standard in journalism, to make journalism better, to protect journalists and to have penalties if any journalist violates the code of conduct. This way, the facts provided by the press are analyzed and interpreted so that the people get true information and understandable news. This helps maintain social harmony by revealing social evils like corruption.

Researchers have interviewed 10 different beat reporters who are reporting in Karachi on different beats.

\section{Measurements}

If researcher analyst that which beat, City and province is dangerous for Pakistani journalists so as per mentioned below chats,

As per the CJP report, 81 Journalists and media workers were killed from 2000-2020. 65 journalists and media workers are those who killed confirmed motive although rest were killed with unconfirmed motive.2011 was the most dangerous year for the journalist and media workers in which 11 journalists and media workers have been killed by the unknown and known persons. This is the very importing thing that there is not a single year where any journalist was not killed Complete data have been described in mentioned below graph.

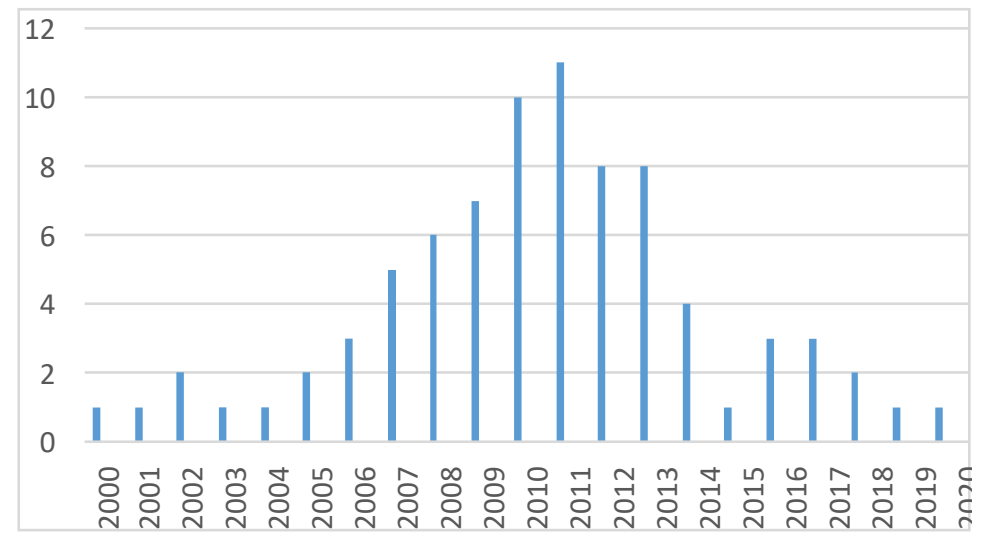


If researcher discuss the data of CJP so we can get these figures that which profession has been mostly targeted? 48\% broadcast journalist, 30\% cameraman, 3\% technician, and 19\% media workers were targeted. The detail is mentioned below in the graph.

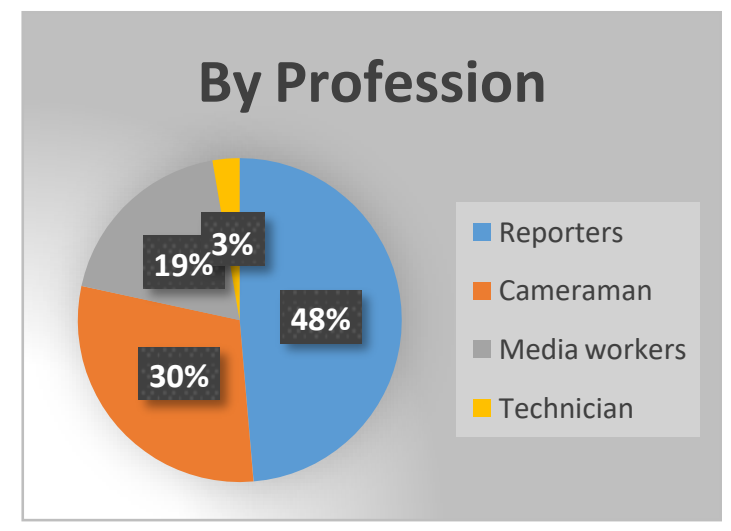

Usually, researcher thought crime beat is the most dangerous beat in the media field but as per the data of the CJP political beat is the most dangerous beat in the media field in which 15 political beat reporters were killed in the line of duty although 7 crime reporters, 4 Human rights reporters, 3 were belonging to anti-corruption beat and one from commerce beat. Sport and culture are those beats that are safer for journalists and media workers.

The detail is mentioned below in the graph.

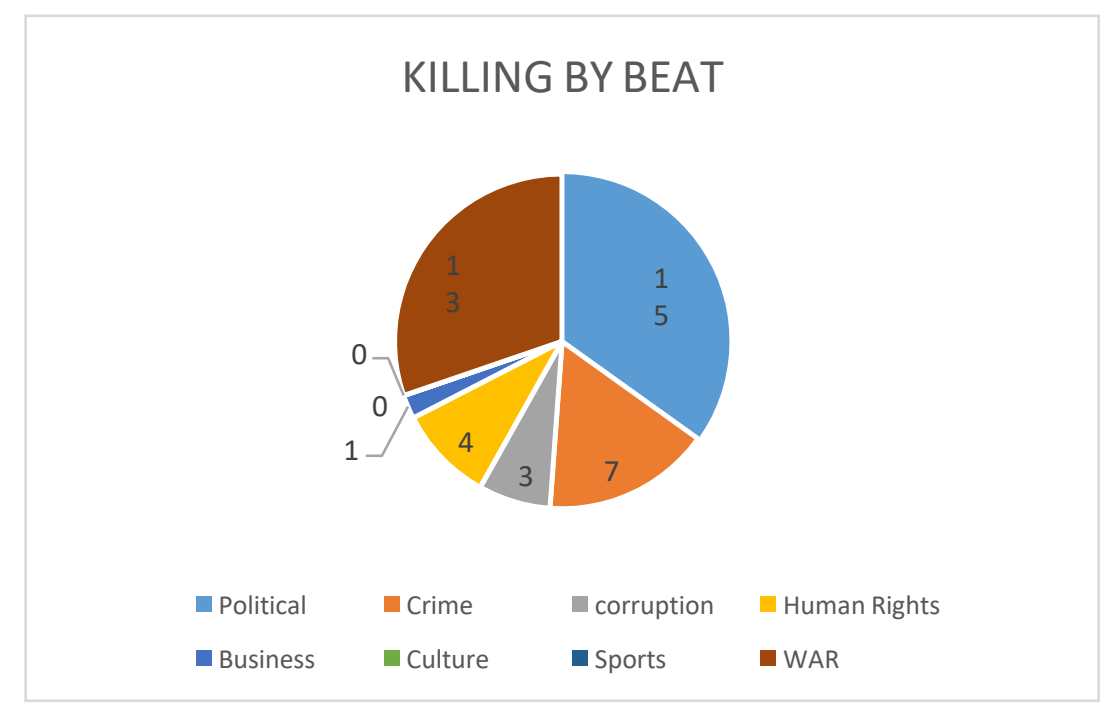

If researcher categorize the killing of journalists by their organizations so it's also alarming that the freelancer's life is riskier than other corporate channel's journalists if we examine the data of CJP so we knew that 9 freelances were killed by terrorist/unknown persons. 6 were connected with Samaa TV 7 were Express TV, 4 were Geo TV, 3 were from AAJ TV and the rest were from local channels. 


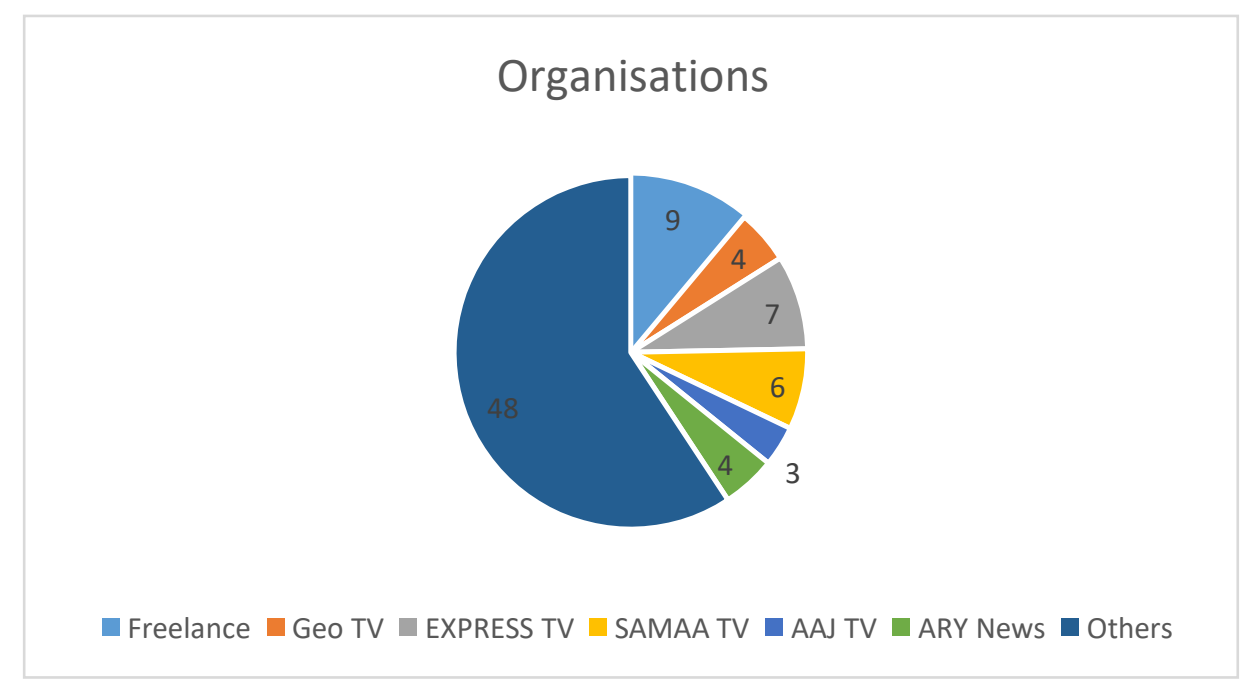

As per the report of Press Freedom report 2020, a total of 90 cases researcher registered against media workers. If researcher examine the data so 2 were forcibly abducted/missing, 10 were attacked by goons/unknown persons, 23 were threatening, 10 were censored from media, and 8 were those who were snubbed by the legal way. On the other side the capital of Pakistan, Islamabad is the most dangerous city for journalists which reported 91 cases against the journalists, which is $34 \%$ of the total crime against the journalist.

Although Sindh province is the worst province for the journalist which is $27 \%$ of the total crimes against journalists, Punjab is the second-worst province for journalists, KPK on $3^{\text {rd }}$ and Baluchistan is the bottom province with $3 \%$ of the total crimes against journalists.

Data is mentioned below in the graph.

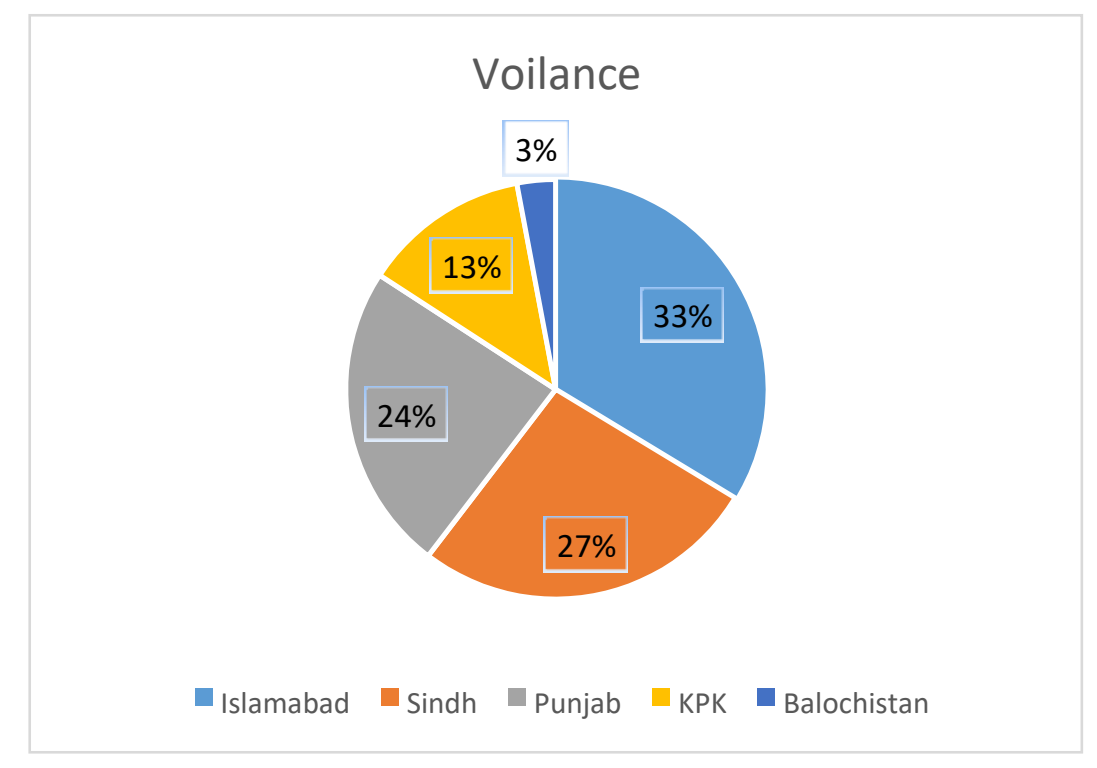

\section{Discussion}

With 340 journalists killed in the line of duty, Iraq topped the list of the most dangerous countries for working journalists, followed by Mexico with 178 journalists, the Philippines with 178, Pakistan with 138, and India with 116 journalists. 
The International Federation of Journalists (IFJ) has confirmed the deaths of 42 journalists and media professionals in 15 countries as a result of targeted attacks, explosives, bomb explosions, and crossfire events so far this year.

Mexico leads the list with 13 killings for the fourth time in five years, followed by Pakistan (five), India, Afghanistan, Iraq, and Nigeria (three each), the Philippines, Somalia, and Syria (two each), and Cameroon, Honduras, Paraguay, Russia, Sweden, and Yemen (one each).Since 1990, assassinations of journalists in Pakistan (138) and India (116) have accounted for nearly every year on the list in the India Subcontinent, accounting for 40 percent of all journalist deaths in the Asia Pacific area.

\section{Conclusion}

What follows is overall safety guidance for newsrooms and journalists who report on hate clutches and the stages where they assemble online.

\section{- Before and while reporting}

Maintain a robust security posture when conducting research and reporting to keep prospective harassers from discovering your personal information. Much of the information in this article comes from security trainers at Equality Labs and Tall Poppy, two groups that specialize in online harassment and threats, as well as my own experience on the beat.

It also contains information that might assist newsrooms in providing assistance and protection to reporters working the online hate beat.

\section{- Download and begin using a secure password manager}

A password manager is programmed that stores all your keys and assists you in keeping track of them as well as creating composite and distinct passwords for each account. Change or reset all your passwords with your PIN manager to guarantee you're not using the same password on multiple sites and that each password is difficult to decipher. You may have more internet accounts than you realize, so making a list may be beneficial. When changing passwords, use a two-factor verification method if one is available.

\section{- Visit the sites you're interested in using a Virtual Private Network (VPN)}

VPNs conceal the origins of online traffic. If you're poking about on a website and visiting it frequently, your IP address, site, or other identifying information may alert the site's owners that you're digging around. Do your homework since some VPN services are more reputable than others? Private Internet Access is recommended by Equality Labs. Wirecutter also offers a good selection of VPNs to choose from.

\section{- Tighten your social media privacy}

As much identifying information as possible should be exposed on all your social media profiles. Take a picture of who is succeeding you on your private accounts and ensure that no identifying information about where you reside is placed in any communal house or shared with society who may compromise your security. Consider unfriending your domestic memberships on social media and explaining why they are unable to publicly reveal their affiliation to you online. Similarly, be aware of any community mailing lists to which you may have subscribed and urge the email list's moderator to remove any correspondence including your phone number or address from the community archive. 


\section{- Ask your newsroom or editor for support.}

"News studios have a maintenance obligation to their personnel to supply the tools that they require to be safe," says Tall Poppy CEO Leigh Honeywell. Disbursement for facilities that remove your data from data agent sites, as well as a high-quality password administrator, may be included in those products. If you're personal information begins to circulate, your newsroom should be prepared to communicate with social media platforms to report abuse and request that the information be removed. Newsroom management could also consider implementing internal rules about how to protect their journalists in the event of online harassment, which could include sifting through fears posted on Twitter and implementing a front desk strategy that instructs anyone answering the phone not to reveal information such as whether a journalist's effort at work is up to par.

\section{References}

ANI. (2020, December 12). 138 journalists killed in Pakistan since 1990. Retrieved from https://www.aninews.in/news/world/asia/138-journalists-killed-in-pakistan-since$199020201212131816 /$

CJP. (2020, December 30). Committee to protect journalists - Defending journalists worldwide.

Retrieved

from https://cpj.org/data/killed/2021/?status=Killed\&motiveConfirmed\%5B\%5D=Confirm

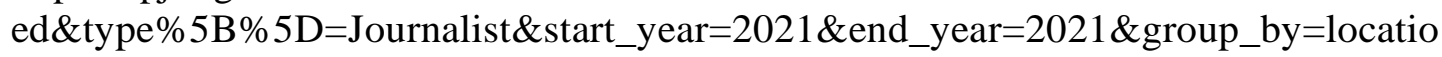
$\mathrm{n}$

Mexico elections 2021: Journalist safety kit. (2021, April 19). Mexico elections 2021: Journalist safety kit. Retrieved from https://cpj.org/2021/04/mexico-elections-2021journalist-safety-kit/

Pakistan Press Foundation. (2019, January 1). State of Pakistani media in 2018 | Pakistan press Foundation (PPF). Retrieved from https://www.pakistanpressfoundation.org/state-of-pakistani-media-in-2018/

Pakistan Press Foundation. (2019, January 2). 72 journalists murdered in Pakistan since 2002 Pakistan press Foundation (PPF). Retrieved from https://www.pakistanpressfoundation.org/72-journalists-murdered-in-pakistan-since2002/

Pakistan Press Foundation. (2020, March 9). Pakistan- KP women journalists form network to raise voice for their rights | Pakistan press Foundation (PPF). Retrieved from https://www.pakistanpressfoundation.org/pakistan-kp-women-journalists-formnetwork-to-raise-voice-for-their-rights/

Taliban fighter beats freelance journalist SadaqatGhorzang at Afghanistan-Pakistan border crossing. (2021, October 25). Retrieved from https://cpj.org/2021/10/taliban-fighterbeats-freelance-journalist-sadaqat-ghorzang-at-afghanistan-pakistan-border-crossing/

The Economic Times. (2019, September 5). Pakistan most dangerous country, its leaders don't care about their people: Jim Mattis. Retrieved from https://economictimes.indiatimes.com/news/defence/pakistan-most-dangerouscountry-its-leaders-dont-care-about-their-people-jimmattis/articleshow/70993529.cms

The News. (2016, May 3). Pakistan fourth most dangerous country for journalists. Retrieved from https://www.thenews.com.pk/latest/117196-Pakistan-fourth-most-dangerouscountry-for-journalists 